\title{
TRIBUTES
}

\section{A FOND FAREWELL}

\author{
W. Edward Sell
}

With the graduation on May 22, 2004, two valued members of the law school faculty retired. Not only were they valued members of the faculty, but they were two of my personal friends. Because I had a significant role in their law school education and their hire onto the faculty, it is difficult to put into words my deep feelings about their departure. Therefore, I present this tribute with mixed emotions - happy for them but sad to see them depart.

\section{CYril A. FoX, JR.}

I had "Cy" as a student during his school years, 1962-1965. Also, as a Faculty Advisor of the University of Pittsburgh Law Review, I worked with him in that capacity. He graduated in 1965 . I saw in him a person of strong intellect and outstanding lawyerly qualities. I followed his career after his graduation and in $1968 \mathrm{I}$ approached him concerning his interest in coming back to the law school as an adjunct professor. He agreed and served in that capacity from 1968 to 1971 .

During the period of his service as an adjunct faculty member, my then Associate Dean John Murray and I received many favorable comments about

* W. Edward Sell passed away shortly before publication of this issue. Dean Sell began his career at the University of Pittsburgh School of Law in 1947, and served as dean of the Law School from 1966-1977. Dean Sell also served as a faculty advisor to this Law Review, providing guidance and a nurturing hand to the editors and staff. As the Distinguished Service Professor of Law Emeritus and Dean Emeritus, Dean Sell continued to teach a full course load at the age of 81 . While we are all saddened at his untimely departure, we are all richer for having lived, laughed, and learned with him. 
Cy's teaching and the standards of professional conduct he espoused in his teaching. Accordingly, in 1971, we proposed him for a full-time faculty position. He was voted on favorably and began what turned out to be an outstanding tenure of thirty-three years of full-time service. During most of those years, he served well as the school's liaison with the Pennsylvania State Board of Law Examiners.

As a teacher, he ranks among the best in the field. Twice he has been voted the Excellence in Teaching Award by the senior class. He is always eager to answer student questions in class or meet with them in his office. He has considered this a primary responsibility and has discharged it in an admirable fashion. He has always felt that the primary mission of a law school is to train its students to enter the practicing profession and conduct themselves in the highest manner both intellectually and ethically. His mission is evident to his students, present and past.

He has under girded his excellent performance in the classroom with scholarly efforts in the field of property law. He has written both for the law school community as well as the practice field. I have been honored by being his coauthor on a treatise for practicing lawyers.

$\mathrm{He}$ has served the profession by contributions to Bar Association activities. He has been active in the Eastern Minerals Foundation. In addition, he has served as a consultant to lawyers and groups in property matters.

In all of this, Cy has been self-effacing. Never one to grab the limelight, he is very reticent about chronicling his own achievements; however, that is not a fault but an admirable attribute.

I have found him to be a great colleague. When Cy does not agree on a point, he is not one to take issue in a nasty way or to hold a grudge if the decision does not go his way. He has been a real team player over the thirtythree years.

On a more personal note, he has been one of my closest friends on the faculty. He has been a confidant as well as one who has given freely of his opinion when I have asked it of him.

In short, I am losing a gem of a friend. While I will miss him around the school, I look forward to our continued friendship. My wish for him is that he will have a happy and successful time in whatever he does in the future. He certainly deserves it. 
Robert B. HARPer

Again, I am saying goodbye to a former student, a colleague, and a dear friend.

Bob graduated in 1971. I had him as a student and was impressed with his maturity and dedication to his studies. He obviously wanted to be a lawyer.

Again, while I was Dean of the school, I saw the need for an Assistant Dean to work in student recruitment. At that time, the school did not have an admissions officer.

I approached Bob about the idea of his joining my administrative staff. He accepted my offer and became Assistant Dean for Student Affairs in 1972. When he joined the staff, I afforded him the opportunity to teach a course. When I was preparing to retire as Dean in 1976, I advised Bob to make a decision whether he wanted to be in administration or teaching and he chose the latter.

While he was Assistant Dean, he and I enjoyed many trips to visit college pre-law groups. Always Bob was a big hit with the students. Invariably, I would end up with the Faculty Advisors and a few students while Bob was entertaining most of the students. However, this was not unusual if you know Bob. He always walks around with a smile. He always demonstrates a positive attitude. During our years together, I cannot remember Bob engaging in complaining. I was proud of my decision to invite Bob to join my administration.

As a professor, Bob enjoyed his students and spent much time with them. He was invaluable for the advice he gave to students who sought his views.

In the community, Bob has been an ambassador of goodwill for the school. He serves on the Board of Neighborhood Legal Services. He has been active in numerous professional efforts, many involving minority members of the bar.

But it is a friend that I will most miss in Bob's departure. Always a lot of fun in conversations, he would do anything for anyone. I remember one of his sisters telling me how devoted Bob was to his mother and to his siblings. I am proud to count Bob among my close friends. I am certain in the years ahead he will find new ventures. My every hope and wish is that in whatever he does he will find happiness, success, and a sense of accomplishment. He certainly deserves no less. 



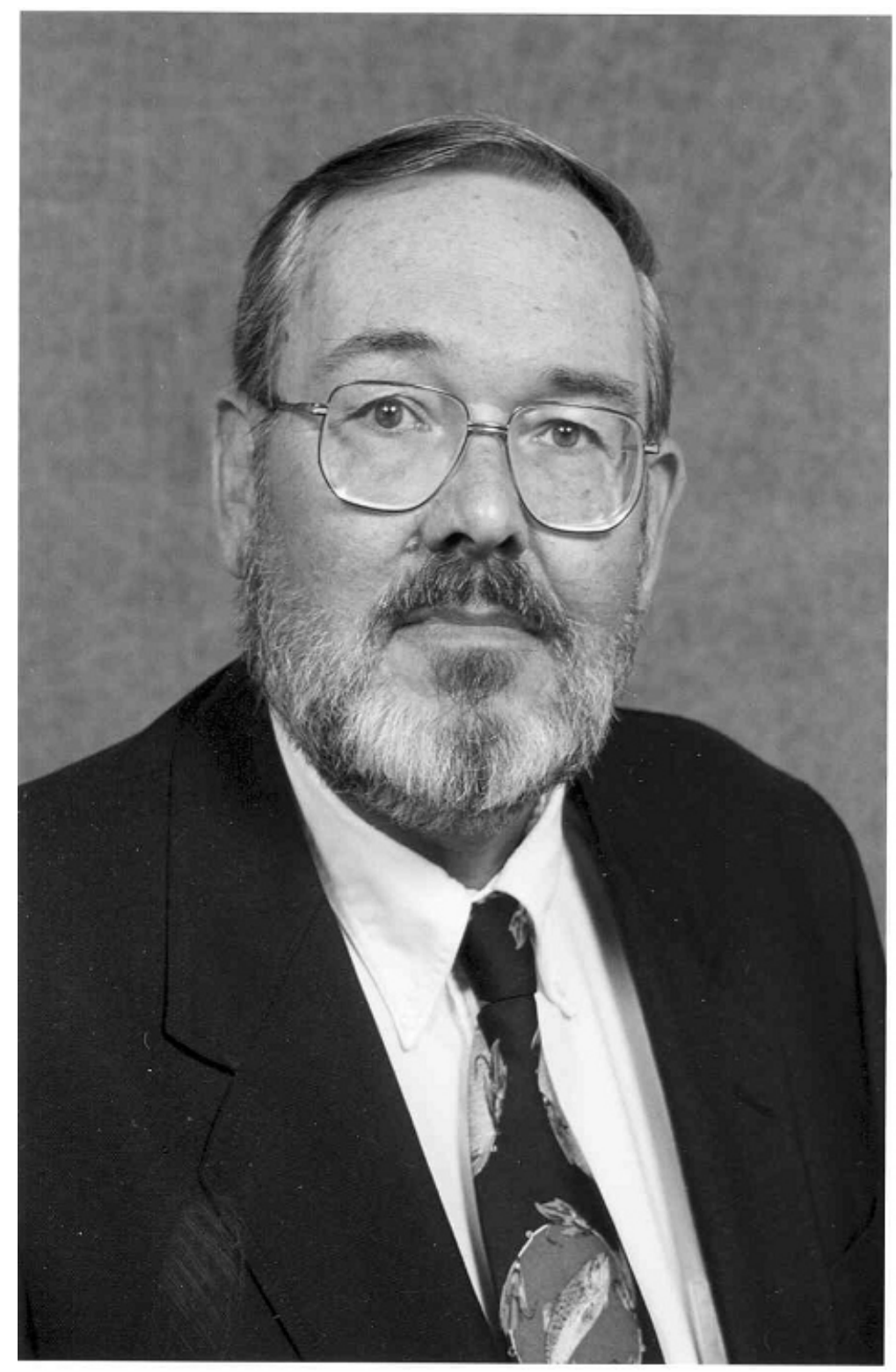

Cyril A. Fox, JR. 

A TRIBUTE TO PROFESSOR CYRIL A. FOX, JR.

\author{
Professor Lawrence A. Frolik
}

Cyril A. Fox, jr. is retiring from the faculty of the School of Law after a 33-year career, which began in 1971 when he was appointed as an Assistant Professor. His participation with the faculty, however, actually commenced in 1969 when he was named an Adjunct Professor, and his association with the School began with his matriculation in 1962 and his graduation in 1965.

$\mathrm{Cy}$, as he is known to one and all, has had a distinguished tenure as a loyal, dedicated, and successful member of the faculty. Over the years that he has served here, and thanks in no small measure to his efforts, the School has grown in both stature and size. The faculty has gone from 14 faculty members to over 35. The number of students has more than doubled and the qualifications of those students has never been higher. A regional school has become nationally prominent, attracting students from across America. He leaves having helped build one of the nation's finer law schools.

Cy's career spans the last years that the School spent in the Cathedral of Learning, with its cramped library, cavernous class rooms with obscuring pillars, and the dreadfully slow Cathedral elevators, through the move to the new building on Forbes Avenue with its then state of the art classrooms and spacious library, to today's building that is being remodeled to bring it up to date with the world of computers. Throughout these many changes there has remained one constant: the dedication and professionalism of Cy Fox.

In January of 1976 the School moved to the new building on Forbes Avenue. At that time I was in my second semester of teaching and assigned to teach a section of Estates and Trusts, for which I was only marginally qualified. Consequently I spent most of the semester desperately learning the intricacies and the arcane law of wills and trusts, estates, and future interests. Luckily for me, I found my own teacher.

In the new building, my office door opened directly across from Cy's office. As it happened, he taught the other section of Estates and Trusts. Naturally I soon found myself frequently visiting his office seeking answer to questions as diverse as what is the Pennsylvania law of intestacy to just how

\footnotetext{
* $\quad$ Professor of Law, University of Pittsburgh School of Law. Professor Frolik currently teaches Elderly and the Law, Employee Benefits, Literature and Law, and Torts.
} 
does a springing executory interest spring. Cy was always available and always had the answer.

$\mathrm{Cy}$ had an open door policy, both figuratively and literally. If Cy was in his office, his door was open. That physically open door symbolized that he was available to anyone in need of his assistance or counsel. Shamelessly taking advantage of Cy's good nature and willingness to teach anyone at any time, I used Cy as my personal avatar. I would enter his office, sink into one of the easy chairs, ask a question and so begin my lesson in estates and trusts. After answering my particular inquiry, Cy would move on and supply answers to questions I didn't even know I should ask.

The conversations were held in a cloud of aromatic pipe smoke, for in those benighted days smoking was still permitted in the building. Perhaps it was because I was a former smoker, but I took a particular comfort sitting in Cy's office, sipping a cup of coffee in that haze of smoke while we discussed all manner of things ranging from the history of the fee tail to the difference between bequeathing personalty and devising property. We talked of teaching methods, law, and the best fishing holes to be found in western Pennsylvania. Cy also instructed me about local politics, campus intrigues, and even where to get a good pastrami sandwich. In short, Cy was my trusty guide to law and life in Pittsburgh.

The only impediment to visiting Cy in his office was that it seemed that there was always a student there talking to him about who knows what. They could not all have been in there asking what is a fee simple or for an explanation of The Rule in Shelley's Case. No, they, like I, were there for far more than just information about the law. They were there to capture Cy's wisdom and to partake in the comfort offered by an approachable professor. Unlike some other professors who might appear aloof or who were physically absent, Cy Fox was always willing to talk to a student. From Cy I learned that you could know the answers without appearing arrogant. I learned that you could be receptive to and respect students without being a doormat or pander to them. And I learned that the job of teaching did not end with the classroom.

After a few years, Cy gave up teaching estates and trusts and moved on to the law of coal and mineral interests. It was a natural progression for a man who, because of his success as a teacher in the first year course in Property law, was known to the students as "Mr. Property." You have to understand that the law of mineral rights is pretty arcane material. Most schools don't even offer a course in it. The few that do generally rely upon adjuncts, lawyers whose work gives them an intimate knowledge of the field. For Cy to take on this course demonstrated his willingness to master a complex and confusing set of federal and state laws and regulations that overlay the 
traditional common law of property. With no one else on the faculty having any knowledge of the area, Cy was on his own. But soon he mastered the law so well that he later co-authored a casebook on the subject. He also joined and eventually became a leader in the Eastern Mineral Rights Foundation, an organization composed of lawyers whose practice involved the stuff of coal leases, oil rights, and the like.

That $\mathrm{Cy}$ would succeed with practicing attorneys is hardly surprising. $\mathrm{He}$ once said to me that he considered himself a lawyer teaching in a law school. He never saw himself as an academic who happened to teach law. In some ways I think that encapsulates his attitude toward his work. $\mathrm{Cy}$ is a lawyer, with all the good traits we associate with lawyers, preferring to teach young people (and some not so young) how to become lawyers. For Cy, law school is not some ivy covered tower, but the first stage in a long career as a lawyer. He viewed helping fledgling lawyers in the first days of their careers as a real honor. Teaching mattered to $\mathrm{Cy}$. It mattered to him that his students learned how to think like lawyers, learned the substance of the law, and learned to appreciate the ethical responsibilities and obligations of the profession. To $\mathrm{Cy}$, law school is not separate from the legal profession, but its very foundation.

Cy likes lawyers. Many days I would see him putting on his squashed Irish hat as he left to take the bus downtown for a meeting of some group of local attorneys. For $\mathrm{Cy}$, interacting with attorneys was as natural as a fish swimming in a stream. Even his annual spring fishing trip to rural Pennsylvania was often made in the company of lawyers, some of whom had once been his students. Upon his return, his talk was not of the fish, but of the good times with those lawyers.

In addition to his casebook, he for years was the editor of the book that published the papers delivered at the Annual Eastern Mineral Lawyers Institute. Cy spent countless hours to convert the submitted manuscripts into articles worthy of the printed page. His later years saw him take on the burden of teaching a course in land transfer and finance, yet another very difficult course that in many schools would have been relegated to an adjunct. He did so, in part because of his interest in the field, but also from a belief in the importance of the material.

In the law school community, Cy was always the voice of moderation. Though he never failed to speak his mind, he did so in a manner that implied that reasonable minds might disagree. Typically in a faculty meeting, $\mathrm{Cy}$ would begin his statement with the phrase, "I think there are good points on both sides here but. ..." He would then go on to express his views, which 
might or might not win the day, but he always presented them in a way that helped bring the group together.

Cy frequently chaired the critically important Faculty Curriculum Committee, where he faced the thankless task of creating a coherent curriculum that satisfied the demands of students and the desires of the faculty. When Cy took on a task, however, you knew it would be done right. His success in that capacity mirrored his accomplishments as a teacher and a scholar. It is typical of his dedication to the School that even in his last year on the faculty he served as Chair of the Curriculum Committee.

For $\mathrm{Cy}$, retirement from the faculty is not so much retirement as it is a return to the life of a practicing lawyer. He departs and leaves the rest of us behind to carry on the duties of an academic. Though sad at his departure, for we will all miss him and his "open door," our sense of loss is tempered by the knowledge that for many years to come, wherever he goes, there will be an office door open to those in need of information, support, and friendship.

Yes, there will be a new professor hired to take over his faculty "slot." And yes, despite his absence, the School will remain strong. Yet Cy's departure leaves a large gap in the collective fabric of the faculty. He will be missed as both a colleague and a friend. But we wish him well, secure in the knowledge that his departure is but the prelude to new challenges and new contributions to the law. In the words of the poet Milton, $\mathrm{Cy}$, the preeminent Professor of Property, goes forth " $[\mathrm{t}]$ omorrow to fresh woods and pastures new." 
TO CYRIL A. FOX, JR.-COUNSELOR AND FRIEND

\section{Mark R. Hornak*}

Cy Fox often forgets that he was supposed to be "only" an academic. For three decades, as he helped thousands of law students through the intricacies of the Rule in Shelley's Case, or watched them calculate a "life in being plus twenty one years" for the Rule Against Perpetuities, he failed to appreciate that law school was supposed to be an amalgam of theory and confusion, not the place for his teaching law students about helping real people solve real life problems.

On my first day of Estates and Trusts twenty-five years ago, entry to the classroom closely resembled the Oklahoma Land Rush, as sixty students fought for the twenty seats in the front row. We all consciously knew that if we had any hope of mastering a subject created by kings and queens centuries ago, we had to be close to the action. What we did not say out loud, but knew in our hearts, was that we also wanted to be proximate to a skilled teacher, and a consummate lawyer, as he practiced his craft. Twice, the students of the Law School have recognized Cy as a Teacher of Excellence. What they did not know was that they were simply noting for the record, as we lawyers like to say, that he has always considered it to be his honor to pass along to the rest of us not only a body of law upon which much of our society rests, but the obligations of being a lawyer.

Cy has always been first and foremost a lawyer. Every day, in every class, the connection between the black letter legal rules and how they affect the lives of people and the decisions of businesses and institutions has been at the forefront. In a Cy Fox class, mentioning public policy is not uttering a legal platitude, or delivering a quick fall back answer from a fumbling student, but is the springboard for discussion about what the law was and should be. For Cy, talking about the arcane distinctions between replevin and trover is not only an exercise in disciplined thinking, but an effort to have students learn all of the rules, because only be mastering the entire body of law can we as lawyers understand, and then represent, our clients.

* $\quad$ B.A. 1978, J.D. 1981, University of Pittsburgh. Mr. Hornak previously served as Editor-inChief of this Law Review, and practices law in Pittsburgh as a partner in Buchanan Ingersoll, PC. He was a student of Professor Fox's. 
In Pennsylvania, our certificates of Bar admission denominate us not simply as "attorneys at law," but also as "counselors at law." I have often wondered if that appellation was at Cy's direction, or at least suggestion, since what permeates both his law teaching, and his conversations about the law with his students, is the idea that the career we embark upon as we leave law school is not simply a way to earn a living or entertain our intellect, but is a special and trusted vocation. We are given our client's trust and innermost secrets. Often, the work of a lifetime, or freedom itself, is placed in our hands. Our clients are interested in what the law says about their problem, but what they really want to know is what to do-no theory, just a plan of action. For $\mathrm{Cy}$, that rock hard reality is what legal education is all about.

From his corner office on the Law School's fifth floor, Cy Fox jr. (not Jr.) could, if he so chose, rule from the loftiest of the ivory towers. While there are few who can match the intellectual horsepower he brings to the world of property rights as they have been defined and updated through the ages, he is very much a part of the larger world. From his service to the citizens of the City of Pittsburgh in its Law Department, to the scholars and wildcatters who each, for their own reasons, follow the work of the Eastern Mineral Law Institute, Cy has honed his classroom talents in the hurly-burly "real world" in which his students would later practice.

Lawyers, at least those that are any good, inevitably develop a bond of trust and confidence with their clients. While I suppose it is possible to be an effective legal practitioner without genuinely enjoying people and learning about their lives, it is not a recipe for success. Whether you had Cy Fox in class or not, every student has always had a friend and advocate in Cy. For him, an "open door" policy is not a term of art, or a catch phrase in a Law School recruiting piece, but part and parcel of the man and the teacher. Being a lawyer is hard work, and being a law student is the first introduction to the demands and sacrifices of our profession. Whether answering a simple question about the law, or confronting the complex questions about being a lawyer (and a parent and a spouse and a citizen), there is no topic that could not be the subject of his advice based on his experience. For that, and not just the legal nuggets, generations of students are both thankful and indebted.

The best professions, and best professional schools, are of course continuing, evolving institutions. It is that continuity that gives them the strength to weather societal changes, to meet new and increased demands, and to accommodate developing trends. The University of Pittsburgh School of Law is, thankfully, among those steady enterprises. Even with that truth before us, however, it is impossible to say that Pitt Law will be, or can be, the same after Cy Fox's retirement at the end of the 2004 term. What can be said 
with confidence is that our profession is greater, and the needs of clients are far better served, because his fingerprints are all over thousands of lawyers, young and old, in Western Pennsylvania, and far beyond. 



\section{FOX ON ROCKS}

\section{J. Thomas Lane*}

Coal and oil and gas are the resources which fueled the great industrial revolution in America. Were it not for the oil from Colonel Drake's first well in Titusville, Pennsylvania, or the coal industry which supplied the core ingredient to the great steel mills along the Allegheny and Monongahela, this revolution would have been much longer in coming. These industries now generate the tremendous energy supplies of the modern era and while the coal and oil and gas industries contributed more to the industrial revolution than any other single resource, history teaches that the coal industry was one of the last to benefit from the modern machines developed during this revolution.

The same may be said of legal education and scholarship on natural resources. A mere 25 years ago, and despite the importance of natural resources to western Pennsylvania, indeed, the eastern United States, there was a scarcity of legal education and scholarship on the topics of coal, oil and gas, and natural resources. The University of Pittsburgh School of Law had limited course offerings as did the West Virginia University College of Law. Not much else existed.

Fox on Rocks was known in limited circles and law students in this part of the country had only a small smattering of offerings on this important topic. Practicing lawyers in the eastern United States had no continuing legal education seminars to attend, at least anywhere close to home.

In the vacuum that existed 25 years ago a small group gathered to venture into a new endeavor with the creation of an educational institution focused on mineral law. After lengthy discussion, an idea matured into a seminar conducted at the Pitt Law School in March 1980. It was the first Annual Institute of the Eastern Mineral Law Foundation. The self-effacing, behindthe-scenes leader was Cy Fox.

With a combination of good topics, good speakers, and good ideas, that first seminar was a huge success. The attendees included the most prominent legal practitioners in the eastern United States. The excellence of that first two-day seminar spawned a great institution. In a short time the Eastern

\footnotetext{
* J. Thomas Lane is a partner with Bowles Rice McDavid Graff \& Love in Charleston, West Virginia. He received his J.D. degree in 1973 from West Virginia University, and is a past president of the Energy and Mineral Law Foundation.
} 
Mineral Law Foundation, later renamed the Energy and Mineral Law Foundation, became the preeminent source of legal scholarship and education on mineral law in the eastern United States. The 25th Annual Institute will be conducted this spring and the 25 volumes of Annual Institute Proceedings, together with a library of unpublished papers on file, represent the best source of legal research and writing on mineral law in this part of the country.

After its auspicious beginning in the Pitt classrooms, the Energy and Mineral Law Foundation has averaged four educational institutes per year, and for those who consider themselves to be mineral practitioners, these institutes are today a "must attend."

How did all of this happen? The answer is simple: a very friendly professor-type had an idea. With pipe smoke always swirling - at least in those days - there was an enthusiasm, a push, a determination, a foresight, a keen intellect, a can-do attitude, always fresh ideas, a spark, a heaving chest, a push at all the appropriate times. There was always firm guidance and sponsorship. Once started there was a mother's watch, a guiding hand and a heavy lifter.

Cy Fox over the years has published as many articles in the Annual Institute Proceedings of the Energy and Mineral Law Foundation as almost any other single individual. He was the chief editor for many years, has served on the executive committee and many other committees, and during the years 1984 and 1985 was drafted as President of the Energy and Mineral Law Foundation. The published articles, committee positions, and offices held do not speak, however, to the quiet guidance and encouragement that is always the core to establishing a new institution.

I, like thousands of law students and natural resource practitioners, am a beneficiary of the availability and excellence in education on the important topic of natural resources. Thus, on the occasion of a well deserved retirement, Cy Fox leaves two enduring accomplishments that are hard to match. He helped create an institution, now permanently endowed, that will offer for future generations a unique educational opportunity, scholarships to law students and a library of scholarship and research on natural resources. He also, through the excellence of his lectures, has helped establish the Pitt Law School as one of the finest we have in a world competing for such a reputation.

It may be said that the stoutest pillar that sustains greatness is education. In turn, the quality of education rests on educators. In a nation built upon its energy resources it is fitting, therefore, that an educator who has met the test of greatness has taught about the natural resources that have sustained us. 


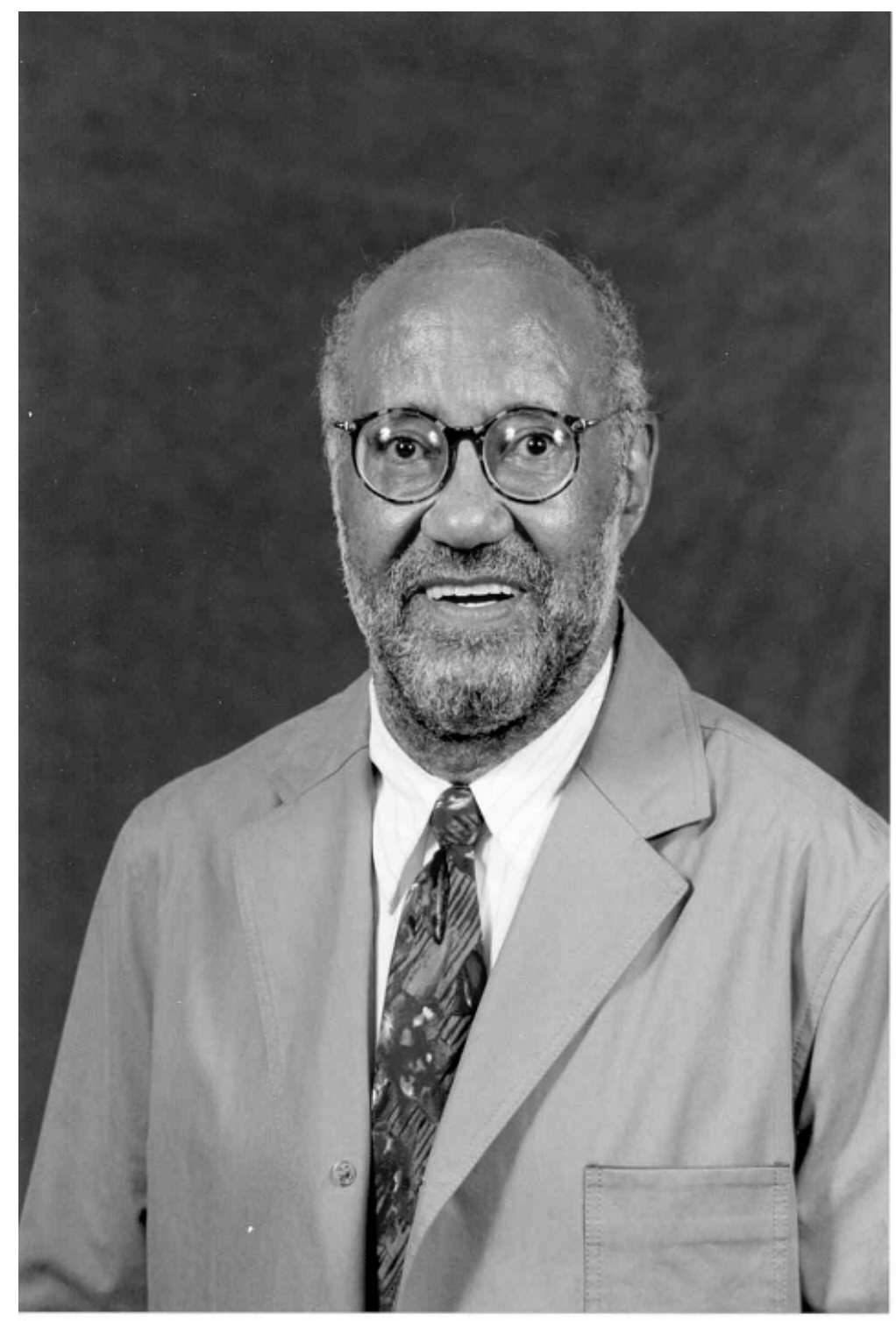

Robert Berkley Harper 



\title{
FAREWELL TO PROFESSOR ROBERT BERKLEY HARPER
}

\author{
Carl G. Cooper, Esquire*
}

"A friend is a need's answer"-Kahil Gibran

In 1977, I began teaching at The University of Pittsburgh Law School and in short order one of my closest friends during my tenure there was Professor Robert "Bob" Harper. I wondered when I was hired whether I was selected because I looked strikingly similar to Bob, and perhaps the faculty thought my favoring Professor Harper would make my assimilation into the law school faculty that much easier. Students constantly called me Professor Harper and, indeed, many on the faculty called me Bob for several years; I never bothered to correct them. I thought if they paid that little attention to detail in law school, I would just let them go through life missing some of the finer points their education, and life for that matter, has to offer.

Professor Harper is one of those finer points in life that we should all pay closer attention to.

He came from a large family whose mother worked diligently to provide a college education for five children and who always had room at the table for more.

He was a former Pittsburgh Public School math teacher and a military man, having served in Korea during the time of the Vietnam War, though he rarely talked about his military experience, in favor of his times in the public schools.

He was the first African-American legal counsel to Pittsburgh Police Department.

He was the first African-American Dean of Students, who handled financial aid, recruiting and admission, all at the same time at the law school. Thereafter, the law school hired a Dean of Admission, Financial Aid Officer and Dean of Students to handle his responsibilities.

\footnotetext{
* Carl G. Cooper currently serves as the Chief Diversity Officer for Kirkpatrick \& Lockhart LLP. Mr. Cooper earned his J.D. from Howard University School of Law in 1972, and previously served as General Counsel of the Housing Authority of the City of Pittsburgh.
} 
He was the first minority faculty member at the law school. He was the first tenured professor at the law school and the first minority full tenured professor at the law school.

He was the president of the Homer S. Brown Law Association for more than two years and talked me into becoming its president in 2000.

He was, and is, an enigmatic personality who was a calming force in a storm, a spiritual leader in the midst of decadence, an articulate scholar who rose above the chatter and dissension of the moment to see the possible in the improbable and the beauty in the way we live out our purpose in life.

Professor Harper told me not long after I arrived from Harvard that I was seen as the "fair haired" chosen one who would be the first to be tenured at the law school. Those who know me realize what an oxymoron it is to refer to me as "fair" or "haired" since I am brown and bald!

But Harper made it seem to apply, and he said it without any malice or envy, just plain matter of fact, and went on to talk about something else, never returning to the subject. For years until I left the law school I never forgot the comment, or as author Iyanla Vanzant would call it in her book The Value in the Valley, of knowing how people devalue your worth, but keeping the faith that you have value and some day it will be realized by others, as it is realized by you today.

Bob made history quietly at the law school, and he made it his way. $\mathrm{He}$ enjoyed teaching and seeing the students develop critical thinking skills, which he hoped some day would serve both the poor as well as the wealthy. Professor Harper treated his role as a faculty member with dignity and respect, and he was always prepared for classroom revelations as the students wrestled with cases that tested their values and their knowledge of life. He knew that some students would grow while others would shrink at the challenges they faced, both in and out of class. His caustic wit and profuse knowledge of the cases orchestrated some of the most interesting and comical class sessions of any academic in the University, let alone in the law school. He enjoyed leaving students perplexed, but not confused, and hoping that they would stretch to find deeper meaning and understanding in the legal reasoning of the courts and issues of social conflict of the day. He consistently admonished students that "we can disagree, agreeably."

Professor Harper made more than just history at the law school; he made a difference in what the face of the legal profession looked like, and for that we can all take pride and comfort in knowing that he paid the price, stayed the course and paved the way for a whole new generation of "diverse" lawyers at the University of Pittsburgh School of Law. Being "first," being the "only," is a lonely road to travel and offers many opportunities to give up or give in. 
Thankfully, Professor Harper stayed in long enough to assure all of us a brighter legal future, a better legal community and a memorable "living legend." We are all the better for his having passed our way, even if only once. As Professor Harper would say: "If you do it right, once is enough." 



\title{
PROFESSOR ROBERT BERKLEY HARPER, TEACHER, MENTOR AND FRIEND
}

\author{
Frederick Wells Hill, Esquire*
}

When I was asked by Dean Edward Sell ${ }^{1}$ to write a tribute to "RB", as I affectionately refer to Professor Harper, I was at once honored and humbled. Honored because I would have an opportunity to talk about and pay tribute to someone who had a significantly positive impact on my life. Humbled because of all of the many students Bob could have chosen to write this piece, he selected me.

So where do you begin to tell the story about someone like Harper? Well, let's start with the facts.

Born to a large family in Pittsburgh's Hill District, Bob Harper was one of ten children. While attending Fifth Avenue High School, Bob was advised by a counselor to forget about college and go to trade school to become a printer, the usual advice to exceptional black students in the 1950s. His parents, neither of whom had completed high school, were also reluctant about his attending college because there were limited opportunities for black people ${ }^{2}$ even with a college degree.

With no scholarships or even loans available for lower income households, and with parents who had limited means, Bob worked at the United States Post Office while attending the College of Arts and Sciences at Pitt, majoring in math and education and graduating in 1961. Upon graduation, he enlisted in the U.S. Army, was commissioned a second lieutenant, and served for almost four years, including a tour of duty in Korea.

\footnotetext{
* $\quad$ Frederick Wells Hill (B.A. 1975, J.D. 1978) is Executive Vice President Marketing \& Communications for JPMorgan Chase, a leading, global financial services firm providing a full range of products and services for corporations and individuals. He lives in New York City with his wife, Lynn Fisher Hill, Esquire (B.A. 1985; J.D. 1988). Mr. Hill is also a member of the Board of Trustees of the University and a member of the Board of Visitors of the School of Law.

1. For the record, I know that the late W. Edward Sell most recently served as the Distinguished Service Professor of Law Emeritus and Dean Emeritus, and after 50 years holds the record for the longest period of teaching at the University of Pittsburgh Law School. However, I graduated in 1978 and will always remember his numerous contributions to the School, including his vision of a new facility, which was realized when we moved into the Barco Law Building. For those of us who remember the cramped quarters in the Cathedral of Learning, he will always be Dean Sell.

2. Between 1949 and 1964, the unemployment rate of Blacks was $114 \%$ higher than for whites. John Hope Franklin \& Alfred A. Moss, Jr., From Slavery to Freedom, A History of African AMERICANS 545 (8th ed., McGraw-Hill 2000).
} 
After leaving the Army, Bob began what would be many "firsts" for a black man, when he was hired by the Pittsburgh Board of Education and taught math at Liberty School. He was the first black faculty member at the school. In 1968, "RB" was among 9 other African-American students who were admitted to the University of Pittsburgh School of Law; he and three of those students graduated in 1971.

Upon graduation, Bob was hired by the City of Pittsburgh, Department of Public Safety as the Chief Legal Advisor to the Police Department. As the first black man to hold that position, he helped give white police officers a different perspective, while ensuring that the rights of arrestees were upheld.

Professor Harper's Law School career began in 1972, as Assistant Dean, Dean of Students. In that capacity, he spearheaded a concerted effort to recruit more African-Americans students. ${ }^{3}$

In 1976, Bob moved from administration to scholarship as an Assistant Professor of Law, the first African-American faculty member at the Law School. He earned tenure six years later in 1982 and a full Professorship in 1986. "RB's" teaching areas included Insurance and Education Law. But his real passions are Evidence, Scientific Evidence and Criminal Law. In total he has taught thousands of students, in more than 28 years.

His publications include a major treatise on Pennsylvania Evidence, ${ }^{4}$ a definitive piece on searches and seizures during arrests in Pennsylvania, ${ }^{5}$ numerous law review articles, ${ }^{6}$ and other scholarly works.

Bob has served on innumerable University and Faculty Committees. In 2002, the University of Pittsburgh Law Alumni honored him with the Distinguished Alumni Award. "RB" is very committed to his community, as demonstrated by his well over 20 years on the board of Neighborhood Legal Services and his service on committees of the Allegheny and Pennsylvania Bar Associations.

Having traveled to well more than 20 countries, collecting African masks along the way and staying abreast of world as well as community issues, he is as my wife ${ }^{7}$ has described him "the perfect dinner guest," a person who can fit in with any group.

\footnotetext{
3. In fact, I was the product of that effort, enrolling in 1975 and graduating in 1978.

4. Robert Berkley Harper, Handbook of Pennsylvania Evidence (Aspen Law \& Bus. 2001).

5. Robert B. Harper, Pennsylvania Arrests, Searches, and Seizures (The Harrison Co. 1983).

6. See, e.g., Robert B. Harper, Affirmative Action Revisited in 1984, 1 Harv. BlackLetTer L.J. 5 (Spring 1984).

7. Lynn Fisher Hill, Esquire, Class of 1988.
} 
So those are the facts about Harper's life—-but wait! There is really more, much more.

I feel compelled to offer observations about three aspects of my relationship with "RB." It should be noted that there are more than just a few of us who know him as a teacher, a mentor and a friend.

The Teacher When RB first started teaching at the law school, it is fair to say that he was not overwhelmingly accepted. We all know that law professors are a special breed, with quirks and propensities that form the basis of good-natured jokes, usually traded over beers or during study group sessions. Now Bob is not particularly quirky, but he would often end his classes with a Socratic-like question, in the finest tradition of legal education. There were certainly other professors who ended their classes similarly. ${ }^{8}$ However, with "RB," some of the students used very derisive language, intended not to tease but to humiliate. When Harper, like almost all faculty, hired a research assistant to help him while he was writing his tenure piece, the rumor-mill at the Law School was that the student, not "RB," was writing the article, a totally baseless charge. ${ }^{9}$

Through all the digs and all the slights, he never lost his temper and never strayed from his goal of coming to every class over prepared and letting his scholarly writing demonstrate his commitment to excellence. From watching him, I learned lessons that went far beyond evidence or criminal law. He taught me the true meaning of "grace under fire." I also learned to ignore the background noise and the clutter that mean spirited people throw in your way and stay focused on the task at hand. And of course, substantively I learned practical, legal strategies that had application in the real world of practicing law. For example, Harper taught me that there is usually a way to get character evidence admitted, despite the limitations. ${ }^{10}$

My Mentor Harper has been and continues to be a wise and faithful counselor to many of us. From advising a young colleague on writing an article to guiding a young lawyer on starting a solo practice, Professor Harper has been dispensing wisdom for many years. The advice has not always been welcomed or pleasant, but it has always been well intended. Those who know

8. Professor Richard Seeburger was so famous for this tactic that he was nicknamed "The Riddler."

9. Professor Harper's articles that were sent out for review for tenure were Robert Berkley Harper, Has the Pennsylvania Superior Court Misread Terry \& Adams?, 20 DuQ. L. Rev. 585 (1982) and Robert Berkley Harper, Accountability of Law Enforcement Officers in the Use of Deadly Force, 26 HowARD L.J. 119 (1983).

10. In my Evidence class, I learned that character evidence, though the courts limit its admissibility, can be admissible in a variety of situations because "[e]vidence of the general character of a party or witness almost always has some probative value." HARPER, supra note 4, at 108-09. 
him know that there are many stories about his very direct approach to offering constructive feedback.

There is probably no finer example of this than the advice given to Rick Gilchrist, a classmate of mine. In the first half of the first year, Rick was known to party hard (probably harder than necessary) to the detriment of his academic achievement. None of this had escaped the attention of Professor Harper, who encountered Rick in the Black Law Student Association Office one evening. The conversation was short, pointed and meaningful. "Mr. Gilchrist," Professor Harper said, "Why don't you just leave now since it is obvious that you are going to flunk out!"

Well, for Rick, that was the wakeup call. He refocused on school, graduated and enjoyed a successful career before succumbing to liver disease. Before he died, Rick told everyone who would listen how appreciative he was for Harper's advice. Rick was emotionally moved that someone had taken the time to care and the fact that his life was ending made it even more important to him. Just before he died, Rick had the opportunity to thank Professor Harper personally.

Whether it was advice to a colleague on the subject of their first article, ${ }^{11}$ or issues around being a sole practitioner ${ }^{12}$ or on deciding whether to leave the practice of law, ${ }^{13}$ Professor Harper has always been faithful and wise, and in his own unique way, very direct.

My Friend One of Professor Harper's favorite expressions, one he has probably used in every Criminal Law class, goes something like this: "If you are worried about getting killed or stabbed, don't worry about strangers, worry about your friends! It's your friends that will kill you!"

Of course, true friends will stand by you when you are alone; support you when you are weak, help when you are needy; listen when you need to talk; give you a shoulder when you need to cry; and give you a hug when you are hurting. And friends don't just buy you birthday cards; they write notes that are meaningful and poetic. "RB" is that kind of friend.

Acts of friendship are communicated in everyday life when people are going through divorces, when a family member dies, at weddings and

11. Professor Sandra Jordan credits Professor Harper with helping her choose the subject of her first piece, Sandra D. Jordan, Classified Information and Conflicts in Independent Counsel Prosecutions: Balancing the Scales of Justice After Iran-Contra, 91 Colum. L. Rev. 1651 (1991).

12. Michael Benjamin, Esquire considers Harper a mentor and a person who "helped me recognize that I could do it on my own!" Michael graduated in 1977 and enjoys a successful plaintiff's practice in Philadelphia, Pennsylvania.

13. Personally, I sought Bob's advice when moving from Pittsburgh to take a job with McDonnell Douglas in St. Louis, Missouri. 
graduations and during serious illnesses. Bob Harper has been to all of those occasions for his friends; sometimes carrying us, sometimes walking at our sides; sometimes providing guidance and support; and sometimes just being there when we needed him.

Professor Sandra Jordan credits "Rob" (as she calls him) for guiding every step of her career moves and decisions; from recommending she accept a job as a federal prosecutor to coaxing her back to the Law School to teach. Sandy went on to become the first black female tenured professor. Commenting on picking up one of his courses next year, Sandy said, "I am proud to say that I will teach Scientific Evidence next year. My dear friend has mastered this complex subject and I am committed to maintaining the standard of excellence that he began with this course."

So Professor Harper, "Rob," "RB," teacher, mentor and friend, we thank you for your contributions to the University, the Law School, your community and our profession. We thank you for your teaching and scholarship and for showing us how not to let the background noise bother us and for those practical things that we remembered and hold dear, in life and in the practice of law. We thank you for mentoring us, sometimes very directly and at times without us realizing it. We thank you for your friendship, always steady and reliable in fair weather or foul. We thank you for your contagious enthusiasm for life and all it has to offer. And we wish you a healthy, vibrant, long and well-deserved retirement. 



\title{
TO ROB: A FOND TRIBUTE TO \\ PROFESSOR ROBERT BERKLEY HARPER
}

\author{
Professor Sandra D. Jordan*
}

We come here tonight to wish the best

And during the process, maybe a bit of jest

To a man who is generous within his heart

Especially in the wisdom that he imparts

My opening statement will tell all

Lest I suffer the sentence of a downfall

I've sworn an oath I cannot lie

Privileged communications I will deny

Here's evidence of an extensive career

Something all need to hear

He who has touched all of us well

Our friend who's integral in our efforts to sell

Law, that is, the education we share

As teachers and mentors and colleagues who dare

My precise mens rea before this act

Is to bring him closer so all will react

As we celebrate a career of achievement

I must be careful to give him the best treatment

From the seeds you planted, the buds have sprung And grown into plants, that's work you have done However, lest we forget-This all started when first we met One of our professors, counselor extraordinaire

The eccentric prof, so demanding and quirky

Cross-examined us, got our minds working

But I digress a moment from my original intent

Let me return to the plan, for which I've been sent

Of whom do we speak, who is this man?

Some call him Robert, not Sam-I-Am!

Others call him "Harps" Some say "RB"

* Associate Profes sor of Law, University of Pittsburgh School of Law. Professor Jordan currently teaches Evidence, Criminal law, White Collar Crimes, and a White Collar Crimes Seminar. 
Would any alias be considered perjury?

Many of you here know him as Bob

But to me he will forever be Rob

Like most of you, I have stories to share

About this Professor, Mentor, and Colleague who cares

Law student days were tough enough

But Professor, you wouldn't let up!

Prodding, encouraging, pushing us on

When we complained, Professor Harper, what is wrong?

You patiently sat us down and explained

Prepare in life and you've already gained

Nothing but the best would you expect

And so we learned to demand respect

Through our careers and our commitment

Our evidence of success is your personal verdict

You can be proud of those whom you pressed

To always strive to be the best!

General counselors, prosecutors, partners are we

Attorneys general, negotiators, advocates you see

Judges, Legislators, directors each

And, oh yes, professors who teach!

You see how many you have reached?

The evidence is overwhelming

And beyond any reasonable doubt

Thousands of us across this land

Can fondly look back to you-THE MAN!

With every new day, you have a chance to learn

With each passing morning, you have an opportunity to grow

So, smell the lavender of life's other side

Know that your talents are sprinkled far and wide

Rob, we love you and wish you the best

And with these thoughts, respectfully, I rest.

GOD BLESS! 


\title{
TRIBUTE TO PROFESSOR ROBERT BERKLEY HARPER
}

\author{
Professor Welsh White
}

I've known Robert Harper since the fall of 1968 when he was in his first year as a law student and I was in my first year as a law professor. After that, he served as Dean of Students under Dean Edward Sell from 1971-74; and since 1974, he has been a member of the law faculty. During that time, he's also become one of my closest friends.

Since I've known Bob for so long, I could tell you stories about things that happened 20 or 30 years ago. And maybe I will touch on one or two incidents. But since most of you haven't known Bob for that long, I thought that you might be more interested in hearing about Bob as he is today.

So I asked a student in Bob's Scientific Evidence class to tell me something about current students' perception of Professor Harper. The student told me that Scientific Evidence was one of the best courses he's had at law school. He raved about Bob as a teacher, and said that all the students had learned a lot in the course and been especially impressed with how much Bob knows about scientific evidence.

Then, he went on to talk about some of Bob's interests. Among other things, he said, "Professor Harper is very interested in Shakespeare. He has quoted and discussed lines from Shakespeare in class." He also warned me that Bob is someone who is "larger than life," so it would be very difficult for me to give a clear picture of him in a few pages.

I agree with the student that it will be difficult, if not impossible, for me to give you a clear picture of Bob in the space I have. Because of Bob's interest in Shakespeare, however, I decided that the way I want to approach this is to try to pick some quotes from Shakespeare that will give you some insight into his character. Because Bob is such a multi-faceted individual, I can't do it with a single quote. But I can at least choose a few quotes that may help to give you a picture of him.

The first one relates to his generosity: "For his bounty, there was no winter in't: an autumn twas that grew the more by reaping."'

\footnotetext{
* Professor of Law, University of Pittsburgh School of Law. Professor White currently teaches Criminal Law, Criminal Procedure, Advanced Criminal Procedure, and Evidence.

1. William Shakespeare, Antony and Cleopatra, act 5, sc. 2.
} 
As anyone who knows Bob can tell you, Bob is and always has been incredibly generous. One example that people within the law school community know about is that he gave a large gift to the law school for the benefit of future students. But there are many other examples that you don't know about. Bob has helped countless people not only in the law school community but also in the wider community. He has served on the Board of the Neighborhood Legal Services for many years. He has gone to nursing homes and done pro bono work (such as preparing wills) for elderly people there. He has written powerful articles identifying problems that the community needs to address. And whenever someone he knows is in need, he has invariably been generous with his time and resources.

Reflecting on Bob's generosity does lead me to one story from the past, however. I remember when Bob was Dean of Students back in the early 70s. A student had turned in something late to the Dean's office and was assessed a $\$ 5$ fine. She appealed to Bob to try to have the fine rescinded. Thinking she could appeal to Bob's softer side, the student talked about what a hardship it would be if she had to pay the $\$ 5$ fine. She said, "Oh, Dean Harper, I've recently become married. We're very poor. If I have to pay an extra $\$ 5$, it will be such a burden. What can we do?" Bob's response was vintage Harper. He said, "Well, Christmas is coming. You never know. Maybe someone will leave something under the tree."

As to Bob's generosity, you may think that story provides a counter-example. But it really doesn't. Instead, the story suggests another quote that applies to Bob: "He is a great observer, and he looks quite through the deeds of men." Law faculty are not noted for their common sense or their acuity in assessing people. Bob is an exception. In assessing people or in deciding what action to take in a difficult situation, he has exceptionally good judgment. As they say in the African-American community, he has "mother wit." On this issue, I can speak from personal experience because I have gone to Bob for advice on numerous occasions relating to both law school and non-law school matters. His advice has always been shrewd, practical, and sound. On the few occasions when I didn't take his advice, I regretted it later.

Another quote that applies to Bob relates to a special gift he has: "His voice was propertied as all the tuned spheres." "B Bob is an excellent scholar. Among other things, he has written the definitive text on the Pennsylvania

2. William Shakespeare, Julius Caesar, act 1, sc. 2 .

3. William Shakespeare, Antony and Cleopatra, act 5, sc. 2. 
Law of Evidence. ${ }^{4}$ But what has always impressed me more than his scholarship is that people, especially non-lawyers, actually enjoy reading his writing. As one example, I remember how jealous I felt when I heard the secretaries in the Document Technology Center talking about how they were working on one of "Professor Harper's education law" articles or essays and that the issues he was discussing were "really interesting." I have never heard comments like that about any other faculty member's scholarship, including my own.

In choosing the quote relating to an exceptional "voice," however, I was not just thinking of Bob's writing but also his spoken words, especially some of the comments or speeches he has made in faculty meetings. Since matters discussed in faculty meetings are confidential, I cannot quote any of Bob's speeches. But I can tell you that, on occasion, he has been extraordinarily eloquent. Those of us who have been on the tenured faculty for more than 15 years would probably agree that a speech Bob made during a tenured faculty meeting in 1989 was the most eloquent and powerful speech they have ever heard in a law school faculty meeting. Since I have been here since 1968, I can tell you that that speech was the best one I have heard in any law school faculty meeting.

I could tell you a lot more about Bob. He has been an extraordinary friend to me and he has had a tremendously positive impact on the law school. I doubt if there has ever been another member of the law faculty who has equaled Bob in the range of contributions he has made to the law school or to the Allegheny County community. Bob told me once that, when he became a lawyer, his goal was to "make doors where there were once walls." During his more than thirty years at the University of Pittsburgh School of Law, he has been remarkably successful in achieving that goal. Which brings me to a final quote from Shakespeare, which I think perhaps provides the most appropriate description of Bob:

This was the noblest... of them all....

His life was gentle, and the elements

So mixed in him that Nature might stand up

And say to all the world, "This was a man."

\footnotetext{
4. Robert Berkley Harper, Handbook of Pennsylvania Evidence (Aspen Law \& Bus.,

5. William Shakespeare, Julius Caesar, act 5, sc. 5.
} 2001). 